\title{
Kindergarten Layoff Decisions, Competitiveness and Effectiveness: Ability Decisions, Care Decisions, Public Good Decisions, In-Group Favoritism
}

\author{
Yi-Gean Chen ${ }^{1}$, Jao-Nan Cheng ${ }^{2}$ \\ ${ }^{1}$ Department of Early Childhood Education, National University of Tainan, Tainan, Taiwan \\ ${ }^{2}$ Department of Education, National Taitung University, Taitung, Taiwan \\ Email: chen1013@seed.net.tw
}

Received June $29^{\text {th }}, 2013$; revised July $29^{\text {th }}, 2013$; accepted August $7^{\text {th }}, 2013$

\begin{abstract}
Copyright $(\underset{2}{ } 2013$ Yi-Gean Chen, Jao-Nan Cheng. This is an open access article distributed under the Creative Commons Attribution License, which permits unrestricted use, distribution, and reproduction in any medium, provided the original work is properly cited.
\end{abstract}

\begin{abstract}
Many kindergartens have been affected by declining birthrates, and it has become difficult for them to recruit students. Due to the consideration of costs and benefits, some have had to lay off teachers to maintain operational benefits. This study focused on the types of layoff decisions made by kindergarten operators, as well as which types of layoff decisions would better benefit kindergarten competitiveness and effectiveness. Using the decision model by Husted and Allen (2008) as the foundation, this study divided layoff decisions into the ability approach, the public good approach, and the care approach, as well as in-group favoritism decisions, based on a literature review. On one hand, it analyzed the differences between various types of kindergartens in making layoff decisions, and on the other hand it explored the effect of different layoff decisions on kindergarten competitiveness and effectiveness. This study extracted 205 managers of kindergartens from the 23 cities and counties of Taiwan for questionnaire surveys. The research results showed that the layoff decisions of kindergarten principals in Taiwan were generally inclined toward the ability approach and public good decisions, while in-group favoritism decisions were less often used. Different types of kindergartens also showed differences in terms of layoff decisions; in-group favoritism decision was used more often in privately operated kindergartens than in religious/ charitable kindergartens. In addition, kindergartens established by religious/charitable organizations were more likely to use care approach decisions, while kindergartens affiliated with schools were more likely to use ability approach decisions; however, the post-hoc comparisons were not significant. In addition, in-group favoritism decisions also had a negative effect on the kindergarten competitiveness and management effectiveness, but ability approach decisions had a positive effect on both of them. Care approach decisions could benefit management effectiveness but they had no significant effect on elevating competitiveness.
\end{abstract}

Keywords: Layoff Decision; Justice Approach Decision; Care Approach Decision; In-Group Favoritism

\section{Introduction}

Many private kindergartens have been affected by declining birthrates, and they have had to gradually cut the number of classes, the number of teachers, or even end operations. According to data from the Ministry of Education's Department of Statistics (2012), from 2007 to 2011, a total of 840 classes was cut, and the number of teachers decreased by 2859 . In addition, 109 private kindergartens closed during 2010-2011. The data highlight that private kindergartens are facing serious challenges, and that it is necessary to lay off teachers in order to decrease the human resource costs. This problem has also occurred in other countries. The American school system has faced it over the last 20 years, and American schools have also laid off teachers (Guthrie \& Datta, 2008). Thus, researchers are concerned with how managers should decide when it is necessary to lay off teachers.

According to the decision model by Husted and Allen (2008), when individuals face dilemmas, they may make ethical deci- sions and non-ethical decisions. The former refers to using justice principles to make decisions, or to using caring approaches to make decisions. The latter refers to not using ethics to make decisions, for instance, using personal preferences to make decisions. Kindergarten layoffs are a dilemma. Should the principals be concerned about the future of the organization and lay off teachers who have worse abilities and performances in order to maintain organizational benefits (New Teacher Project, 2010), or should they be concerned with caring for their teachers and keep the ones who have a greater financial need for their teaching salaries (Sisco \& Yu, 2010)? Principals could use personal preferences and make decisions based on in-group favoritism; keeping in-group members while laying off the out-group (Varma \& DeNisi, 1996). Husted and Allen's (2008) ethical decision-making model includes justice ethics (including the ability approach and the public good approach), care ethics (the care approach), and consideration of personal factors (in-group favoritism approach), and as such, it was suitable to 
be used as the theoretical framework of this study. This study divided layoff decisions into the four types of the ability approach, the public good approach, the care approach, and in-group favoritism, in order to explore the layoff decisions made by kindergarten principals.

One of the main purposes of this study was to understand which types of layoff decisions were more often used by kindergarten principals. There are many types of private kindergartens. Some are established by religious or charitable groups, some are privately operated, some are franchised, and others are affiliated with schools. These kindergartens, with their different characteristics, may differ when they make layoff decisions. For instance, kindergartens established by religious or charitable groups are guided by religious ideals, and may therefore be inclined to use the care approach to make decisions and keep the teachers who need the salary to help their families, while privately-operated kindergartens may be inclined to make decisions based on in-group favoritism to keep the in-group members (Sidanius, Pratto, \& Rabinowitz, 1994). Thus, the second primary objective of this study was to explore whether layoff decisions would differ based on the different types of kindergartens. In addition, even though past studies have shown that layoffs or restructuring may have negative effects on organizational competitiveness and performance (Guthrie, \& Datta, 2008), and many studies have pointed out that layoffs may affect employee work effectiveness (Manela, 2010), since layoffs are still used by many corporations and kindergartens to cope with a shrinking market, it is necessary to research layoff decisions. This study further explored which types of layoff decisions had a positive effect on kindergarten effectiveness and competitiveness, as well as which types had a negative effect, in order to provide a reference to kindergarten operators. A national survey sample was employed in this study, in order to achieve these research goals.

\section{Literature Review}

\section{Theoretical Foundations in Layoff Decisions}

Recently, many researchers have become concerned about whether corporate or school administrative decisions conform to moral ethics (Groves, Vance, \& Paik, 2008; Payne \& Joyner, 2006; Schweitzer \& Gibson, 2008). Relevant studies have shown that when people feel administrative decisions are fair and conform to ethical norms, they will feel psychologically satisfied (Hegtvedt \& Killian, 1999; Ordonez, Connolly, \& Coughlan, 2000). However, when they feel the decisions violate fairness and ethics, they will be angry, sad, and desire revenge (Schweitzer \& Gibson, 2008), and this will to an increase in truancy, theft, and the intentional destruction of public property (Schweitzer \& Gibson, 2008). In companies, organizational competitiveness and effectiveness will be damaged if layoffs cause employee dissatisfaction or a desire to want revenge, engage in truancy, or damage public property.

Ethical decision-making refers to the need for guidance by standards or principles as a basis for decisions when faced with a conflict of interest, so that an individual's rights can reach a reasonable state (Rest, 1986). In Japan, people see employee guarantees as the most important ethics concept in a corporation (Nyaw \& Ng, 1994); therefore, when corporations need to make layoffs, it has to be carried out in an ethical way.

The study by Husted and Allen (2008) highlighted how L. K. Trevino's use of Kohlberg's ethical cognitive development theory to construct an ethical decision making model; however, it cannot cover all situations, because this model does not consider the relationship between individuals and in-group members. Kohlberg only focused on using justice to determine moral development, which is a narrow perspective. The addition of Gilligan's ethical cognition development, using relationship as the basis, would make ethical decisions more complete.

In the model by Husted and Allen (2008), the first step is to make a determination; if it is an ethical dilemma, there should be an ethical determination. This ethical determination includes the assertion by Kohlberg (justice ethics based on rational determination) and the assertion by Gilligan (care ethics based on relationships). During the ethical determination process, personal factors and contextual factors will also influence the decision makers, who will then use their ethical determinations to decide on their actions, which may be ethical or unethical. Regardless of using justice ethics or care ethics as the main consideration for decision-making, both are ethical. However, if personal likes (such as in-group favoritism) rather than ethical norms are the primary consideration, then the decision-making may not be ethical.

The above decision-making models are primarily used to explain ethical decision-making behavior in organizations and behaviors that are not ethical decision-making. In the exploration of the kinds of layoff decisions made by principals and those in charge of kindergartens, this study considered that the decision model by Husted and Allen (2008) could cover both Kohlberg's justice ethics and Gilligan's care ethics, and that it could provide a more comprehensive theoretical framework for study. Thus, the research design used Husted and Allen's (2008) decision model to serve as the theoretical basis for this study and to develop the research framework.

\section{Justice Approach and Care Approach in Layoff Decisions}

Kohlberg's justice ethics and Gilligan's care ethics use different angles to express ethical perspectives and consciousness (Brabeck, 1993). Kohlberg's justice ethics emphasizes the abiding principle of justice without bias (Brabeck, 1993). However, Gilligan's care ethics is concerned with relationships and emotions, emphasizing care and not causing harm to others as the highest principle. She believed that ethical dilemmas are inherently based on the destruction of harmony and interpersonal relationships, while the obligation of ethical decisionmaking needs to respect the dignity and value of each person in the development of sympathy (Brabeck, 1993).

In terms of the current managerial problems faced by the early education workplace, when kindergartens need to maintain operational benefits, the principal or director will lay off teachers. Based on the view of justice ethics, teachers with less ability should be laid off (the ability approach), and unsuited teachers should be the first to be laid off for the public good (the public good approach), while teachers who are most helpful for organizational development should be kept; this layoff decision better conforms to justice ethics. However, on the care level, if it is known that laying off a teacher would result in difficulties for his whole family, or would make it difficult for him to live, the person responsible may consider the situations of individual teachers and choose to lay off someone who will be less affected by unemployment. This conforms to a care 
ethics decision (the care approach). Thus, in general, layoffs are conducted with greater concern for public good and abilities, or with the care approach. Past studies have shown that Chinese companies are more concerned with care approach layoffs, while American companies are more concerned with public good and abilities (Sisco \& Yu, 2010).

Basically, most organizations can use performance and ability as the basis for layoffs, in either the ability approach or public good approach. However, American school organizations also have the potential rule of last-haired first-fired (New Teacher Project, 2010), which means if someone has worked longer in an organization they will have better relationships. New employees will be laid off first, while senior employees with good relationships will be less likely to be fired. This type of layoff decision falls in the care approach category.

\section{In-Group Favoritism in Layoff Decisions}

According to past studies, the assumption that leaders will treat employees fairly rarely stands up to challenges in real organizations; when directors evaluate the performance of subordinates, many are influenced by the effect of interpersonal affect, leading to different scores for the in-group and out-group (Varma \& DeNisi, 1996). Subordinates who are closer to the leaders (the in-group members) will have higher scores, which shows that when leaders evaluate the performance of their subordinates there will be disparate treatment or in-group favoritism.

In organizations, leaders will divide employees into ingroups and out-groups. The categorization standards for these groups are not only based on familial relationships, but also include compatibility, competence, and loyalty (Graen \& Cashman, 1975; Graen, 1976). Past studies have shown that individuals will give special benefits to in-group members, including special care and protection, leading to unfairness (Sidanius, Pratto, \& Rabinowitz, 1994). Based on the effect of in-group favoritism, this study suggested that when kindergarten principals make layoff decisions, they might favor in-group members, especially in privately operated kindergartens, where emotional factors are more likely to cause in-group favoritism.

\section{Institutional Factors That Affect Layoff Decisions}

Past studies have shown that different types of institutions will also affect ethical decision-making (Sisco \& Yu, 2010). Some Taiwanese private kindergartens have been established by religious or charitable groups, some by private families, some are affiliated with school institutions, and others are large franchise kindergartens. Even though institutional characteristics will also affect ethical decision-making, currently there is no empirical data to show what kinds of layoff decisions these kindergartens are inclined toward; this study hoped to further explore this area. Thus, $\mathrm{H} 1$ is proposed as follows:

H1: Different types of kindergartens show significant differences in layoff decisions.

\section{Correlations among Layoff Decisions, Effectiveness, and Competitiveness}

During cost-benefit analyses, many managers choose to lay off employees to decrease human resources costs, in the hope that layoffs will allow the organization to survive or continue development. However, after employees are laid off, their work psychology may be affected, resulting in lowered effectiveness (Manela, 2010), which in turn adversely impacts the overall effectiveness of the organization. For instance, Guthrie \& Datta (2008) pointed out that cutting labor or laying off employees has a negative correlation to organizational profitability or the elevation of organizational assets $(r=-.29)$, and that organizational profitability or the elevation of organizational assets reflects organizational effectiveness and competitiveness. Thus, this study argued that layoff decisions could affect organizational effectiveness or competitiveness.

At the same time, the choice of layoff decisions also implicates the ethical issue of how to lay off employees; should senior employees or young and capable employees be kept? Even though the study by Donald, Hamilton, Susanna, \& James (2011) pointed out that layoff decisions must consider teacher effectiveness to construct fair and just layoff decisions, when many American schools face layoffs, they still use the method of last-hired first-fired, which may cause younger teachers with better effectiveness to be laid off (New Teacher Project, 2010). Thus, decisions based on the relationship approach may harm effectiveness or competitiveness. The principle of last-hired first-fired implicitly contains a relationship approach decision; the longer one works in an organization, the better the relationship. Their rights will receive more attention and it will be less likely for them to be laid off. This may also accentuate how decisions based on the relationship approach may affect school effectiveness or competitiveness. In other words, different layoff decisions may affect kindergarten effectiveness and competitiveness in different ways. This study also focused on exploring which types of layoff decisions benefit effectiveness and competitiveness. Thus, $\mathrm{H} 2$ is proposed as follows:

H2: Different layoff decisions have different influences on kindergarten competitiveness and effectiveness.

\section{Research Method}

\section{Research Structure}

This study was based on the decision model of Husted and Allen (2008). Layoff decisions were divided into four types: the ability approach, the public good approach, the care approach, and in-group favoritism, in order to explore kindergarten principals' layoff decisions. In addition, this study analyzed whether there were significant differences between institutions of different types (privately operated, established by religious or charitable groups, large franchises, affiliated with schools) in making layoff decisions. The research framework is shown in Figure 1. H1 explored and analyzed whether there were significant differences in layoff decisions for different types of kindergartens, and $\mathrm{H} 2$ explored and analyzed the influences of different layoff decisions on kindergarten competitiveness and effectiveness (as shown in Figure 1).

\section{Research Subjects and Sampling}

The subjects of this study were directors of private kindergartens in Taiwan. According to statistical data, there were a total of 1755 private kindergartens in Taiwan (Ministry of Education Department of Statistics, 2008b). This study used the $1: 3$ ratio for sampling, with a target sample number of 300 . In order to make the research sample representative, stratified random sampling was conducted. First, the cities and counties of Taiwan were divided into north/central/south/east, and then 


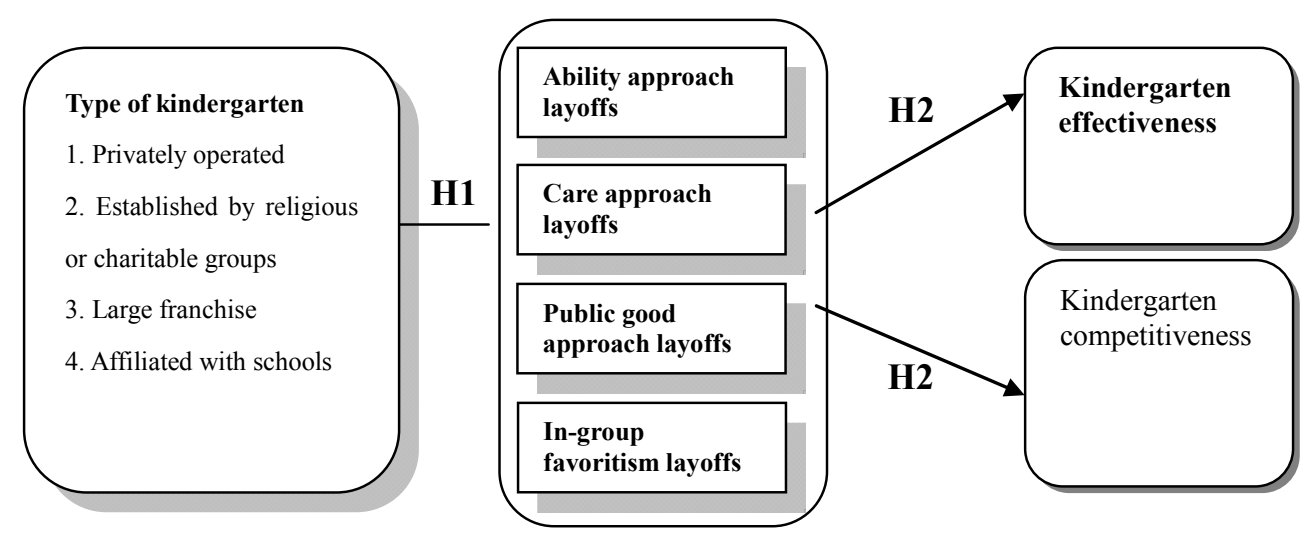

Figure 1.

Research framework.

the number of kindergartens in each region was used to determine the number of samples to be extracted. After extracting the kindergartens, they were contacted by phone to understand who had hiring and firing power. Usually this was the person in charge or the principal. These individuals were then contacted and mailed questionnaires for testing after receiving consent. A total of 205 valid questionnaires were retrieved, including 66 from the north (32.3\%), 36 from the central region (17.5\%), 82 from the south $(39.9 \%)$, and 21 from the east $(10.2 \%)$.

\section{Research Tool and Measurement}

The research tool used was the Questionnaire on Layoff Decisions in Private Kindergartens in Taiwan. The compilation process first underwent expert content validity analysis by four kindergarten principals and two university principals, who provided suggestions for improvement to establish expert validity.

1) Layoff decision questionnaire

This questionnaire referred to items in the Elementary School Principals' Ethical Decision Making Questionnaire compiled by $\mathrm{Su}$ (2007), which was revised in accordance to the purposes of this study. It included decisions based on the ability approach, the public good approach, and the care approach. The section on in-group favoritism decisions referred to items from the In-Group Relationship Questionnaire compiled by Lin (1999) that related to giving special privileges for design. There were two to five items for each of these four approaches, for a total of 14 items. Each question was measured using a Likert 5-point scale. Principal component factoring was used to extract the common factors, and only factors with an eigenvalue $(\lambda)$ greater than 1 were chosen (Joseph, Rolph, \& Ronald, 1987). Oblique rotations were used to derive the four factors, which had reliability coefficients of $.64-.96$ and construct validity of $.53-.95$, indicating that the questionnaire had reliability and validity (as shown in Table 1).

2) Kindergarten effectiveness questionnaire

There were a total of 12 items in this questionnaire, the content of which was based on items from the study by Jiang (2000). Each question was measured using a Likert 5-point scale. Principal component factoring was used to extract common factors from the 12 items, and only factors with an eigen value $(\lambda)$ greater than 1 were chosen (Joseph et al., 1987). Oblique rotations were used to derive three factors, which included instructional quality, group morale, and goal achievement, which had reliability coefficients of $.78-.86$ and construct validity of $.53-.92$, indicating that the questionnaire had reliability and validity (as shown in Table 2).

3) Kindergarten competitiveness questionnaire

The kindergarten competitiveness questionnaire referred to the conceptual definitions in the studies by Garg and Jain (2008), Patten and Ricks (2000), Porter (1980), and West et al. (2004), and there were a total of 19 items. Factor analysis resulted in five factors, including the perception of competitiveness, the quality of flexible service, evaluation performance, student performance, and a low rate of problem students, which had reliability coefficients of .73-.87 and construct validity of .53 - .93; thus, the questionnaire had good reliability and validity (as shown in Table 3 ).

\section{Data Analysis}

Data analysis in this study was primarily based on variance analysis and OLS regression analysis. Variance analysis was used to examine whether different types of kindergartens differed in their layoff decisions. Post-hoc comparisons were conducted. Regression analysis was used to explore the influence of different layoff decisions on kindergarten competitiveness and effectiveness.

\section{Research Results and Discussions}

This study first examined the main approaches used in kindergarten layoff decisions, as well as differences in the layoff decisions at different types of kindergartens. Seen from the means of individual items on layoff decisions, the mean for in-group favoritism was 1.52 points, that for the ability approach was 4.15 points, that for the care approach was 3.38 points, and that for the public good was 4.25 points. This indicated that kindergarten principals in Taiwan believed their layoff decisions were still mostly based on the ability approach or the public good approach. The means for the items on these two approaches were over four points (as shown in Table 4), indicating that each answer either conformed or highly conformed. As for whether layoff decisions used the care approach or were based on concern for the individual conditions of teachers, the answers from the principals showed a medium degree of care approach, with scores ranging between three and four points, which indicated that the answers were between partially conforming and conforming. This result showed slight differences from the research results by Sisco \& Yu (2010), who pointed 


\section{Y.-G. CHEN, J.-N. CHENG}

Table 1.

Summary of factor analysis and reliability analysis of layoff decisions.

\begin{tabular}{|c|c|c|c|c|c|}
\hline Question & 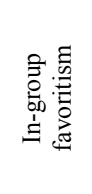 & 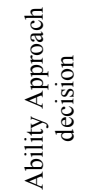 & 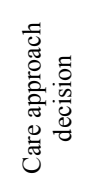 & 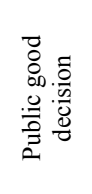 & 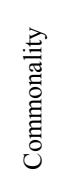 \\
\hline $\begin{array}{l}\text { E17 When distributing work, as much as possible I will arrange easier work for trusted people who are } \\
\text { closer to me. }\end{array}$ & .950 & .015 & .058 & -.013 & .899 \\
\hline $\begin{array}{l}\text { E18 I will not focus too much on work mistakes made by trusted people who are closer to me and I will } \\
\text { protect them as much as possible. }\end{array}$ & .943 & -.018 & -.013 & -.024 & .911 \\
\hline $\begin{array}{l}\text { E19 I treat trusted people who are closer to me better, and it is impossible to treat them the same as other } \\
\text { teachers. }\end{array}$ & .940 & .048 & -.003 & -.002 & .869 \\
\hline E16 In work, I will make things convenient for trusted people who are closer to me as much as possible. & .914 & -.017 & -.010 & .052 & .821 \\
\hline E20 Regardless of the situation, I will not lay off trusted people who are closer to me. & .903 & -.008 & -.021 & -.040 & .842 \\
\hline E4 When making layoff decisions, I will first lay off teachers who are unqualified. & .020 & .841 & .120 & -.204 & .716 \\
\hline E5 When making layoff decisions, I will first lay off teachers with poor abilities. & .013 & .838 & -.078 & .197 & .794 \\
\hline E3 When making layoff decisions, I will first lay off teachers with poor work performance. & -.138 & .638 & -.120 & .340 & .688 \\
\hline E9 When making layoff decisions, I will respect the personal intentions of the teachers. & .003 & -.104 & .809 & .089 & .636 \\
\hline E7 When making layoff decisions, I will place special concern on the needs of the minorities. & .074 & .116 & .700 & .110 & .526 \\
\hline E10 When making layoff decisions, I will first listen to the opinions of the teachers then make decisions. & -.028 & -.075 & .696 & .056 & .475 \\
\hline $\begin{array}{l}\text { E8 When making layoff decisions, I will first lay off teachers who can better bear the impact of being } \\
\text { laid off. }\end{array}$ & -.080 & .139 & .534 & -.324 & .435 \\
\hline E1 When making layoff decisions, I will not have preset ideas, and I will try to be fair in my treatment. & -.079 & .025 & .086 & .879 & .826 \\
\hline E2 When making layoff decisions, I will make public good for the kindergarten the priority. & -.058 & .117 & .098 & .861 & .834 \\
\hline Eigen value $\lambda$ & 5.030 & 2.149 & 1.922 & 1.171 & - \\
\hline Ratio of total variance & 35.931 & 15.351 & 13.725 & 8.366 & - \\
\hline Accumulated ratio & 35.931 & 51.282 & 65.007 & 73.373 & - \\
\hline Reliability & .96 & .71 & .64 & .88 & \\
\hline
\end{tabular}

Table 2.

Summary of factor analysis and reliability analysis of kindergarten effectiveness.

\begin{tabular}{|c|c|c|c|c|}
\hline Question/factor & 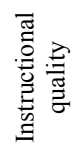 & $\begin{array}{l}\frac{0}{\tilde{J}} \\
\vdots \\
\vdots \\
\vdots \\
\overline{0} \\
\tilde{5}\end{array}$ & 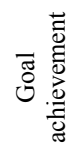 & 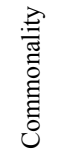 \\
\hline C40 Teachers at this kindergarten are highly confident in their own instructional abilities. & .917 & -.010 & .023 & .816 \\
\hline C41 Teachers at this kindergarten devote their efforts to preparing for instructional activities. & .812 & .009 & -.106 & .752 \\
\hline C39 Children at this kindergarten see learning as a happy thing and enjoy coming to school. & .714 & .003 & -.172 & .647 \\
\hline C38 Parents think that the instructional quality of this kindergarten is very good. & .589 & .187 & -.143 & .591 \\
\hline C16 Teachers at this kindergarten spend a lot of time discussing educational issues. & .179 & .779 & .115 & .670 \\
\hline C15 The Principal of this kindergarten will praise the teachers for their performance. & .070 & .758 & -.028 & .646 \\
\hline C14 The Principal of this kindergarten spends a lot of time on educational affairs. & -.264 & .754 & -.305 & .701 \\
\hline C17 The administrative team of this kindergarten has high morale. & .387 & .530 & .036 & .573 \\
\hline C10 This kindergarten has set some goals to work toward in terms of the children's achievement and performance. & .001 & -.077 & -.864 & .693 \\
\hline $\begin{array}{l}\text { C11 This kindergarten has designed some inspiring educational activities for the learning or future development of } \\
\text { children after their graduation. }\end{array}$ & .139 & -.074 & -.768 & .648 \\
\hline C12 This kindergarten regularly reports to the parents on the children's achievements and performance. & .040 & .153 & -.658 & .577 \\
\hline C13 Children at this kindergarten have serious learning attitudes toward various activities. & .129 & .197 & -.591 & .596 \\
\hline Eigen value & 5.61 & 1.23 & 1.07 & - \\
\hline Explained variance \% & 46.76 & 10.23 & 8.94 & - \\
\hline$\alpha$ reliability coefficient & .86 & .78 & .79 & - \\
\hline
\end{tabular}


Table 3.

Summary of factor analysis and reliability analysis of kindergarten competitiveness.

\begin{tabular}{|c|c|c|c|c|c|c|}
\hline Question/factor & 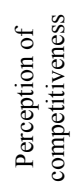 & 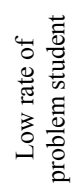 & 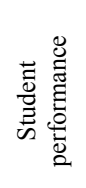 & 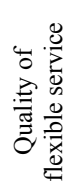 & 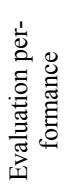 & 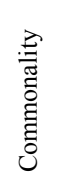 \\
\hline $\begin{array}{l}\text { B15 Teachers at this kindergarten are very concerned about whether it can outperform other } \\
\text { kindergartens and be more competitive }\end{array}$ & .874 & -.028 & -.030 & .051 & .033 & .782 \\
\hline $\begin{array}{l}\text { B16 Teachers at this kindergarten work very hard in hopes of elevating or maintaining the } \\
\text { competitiveness of this kindergarten. }\end{array}$ & .832 & -.021 & -.015 & .001 & .142 & .773 \\
\hline $\begin{array}{l}\text { B17 Teachers at this kindergarten are willing to devote themselves to the sustainable devel- } \\
\text { opment of this kindergarten. }\end{array}$ & .805 & -.047 & -.033 & .110 & .017 & .681 \\
\hline $\begin{array}{l}\text { B14 Teachers at this kindergarten understand very well the intense competition in the market } \\
\text { of private kindergartens. }\end{array}$ & .633 & .058 & .126 & -.053 & -.09 & .437 \\
\hline B82 This kindergarten has many children with behavioral problems. & -.090 & .925 & .039 & .027 & .069 & .850 \\
\hline B81 This kindergarten has many children with learning problems. & -.009 & .916 & .069 & -.038 & .044 & .832 \\
\hline $\begin{array}{l}\text { B83 This kindergarten has many children who are difficult to manage and are troubling to } \\
\text { teachers. }\end{array}$ & -.066 & .819 & -.042 & .112 & .041 & .686 \\
\hline B80 This kindergarten has many children who are unable to adapt to school life. & .149 & .733 & -.082 & -.095 & -.14 & .607 \\
\hline B70 Children at this kindergarten perform well in terms of interpersonal interactions. & -.076 & -.035 & .930 & .043 & -.02 & .834 \\
\hline B69 Children at this kindergarten have good life adaptation. & -.067 & .033 & .920 & .046 & .053 & .843 \\
\hline B68 Children at this kindergarten have good performance in intelligence and learning. & .022 & .023 & .789 & .085 & -.03 & .655 \\
\hline B71 On the whole, children at this kindergarten have good learning performance. & 109 & -.039 & .737 & -.148 & -.01 & .591 \\
\hline B26 This kindergarten provides flexible service times and items to convenience parents. & -.016 & .022 & -.045 & .909 & -.11 & .786 \\
\hline $\begin{array}{l}\text { B27 The administrative operations of this kindergarten are flexible, and the top principle is to } \\
\text { take care of the needs of each parent. }\end{array}$ & -.020 & .006 & .044 & .877 & .003 & .780 \\
\hline B24 Many services and measures of this kindergarten make the children enjoy coming here. & .221 & -.034 & .085 & .531 & .178 & .512 \\
\hline B33 This kindergarten has high administrative efficiency. & .137 & .094 & -.044 & -.047 & .831 & .747 \\
\hline B32 This kindergarten has received outstanding evaluations in many categories. & -.202 & -.050 & -.027 & -.004 & .822 & .616 \\
\hline B34 Teachers at this kindergarten are highly efficient. & .332 & -.009 & .130 & -.041 & .588 & .647 \\
\hline B35 Many educational measures promoted by this kindergarten are very effective. & .195 & .002 & .154 & .145 & .570 & .590 \\
\hline Eigen value & 5.324 & 2.934 & 1.86 & 1.713 & 1.42 & - \\
\hline Explained variance \% & 28.02 & 15.44 & 9.79 & 9.02 & 7.47 & - \\
\hline$\alpha$ reliability coefficient & .83 & .87 & .85 & .73 & .74 & - \\
\hline
\end{tabular}

out that Taiwan and Mainland China both have Chinese societies, and that Chinese companies are more concerned with care approach layoffs. However, this study, using Taiwanese kindergarten principals as the subjects, found that there were greater inclinations toward using the ability approach and the public good approach in making layoff decisions. There were two possible reasons for this. The first was that kindergartens are already facing operational crises, and only ability approachbased layoffs can promote kindergarten survival. The second reason was that there are a number of differences between Chinese and Taiwanese social culture; Taiwan is more democratic and modern, while Chinese rural villages have not fully transformed and still have significant effects from interpersonal relationships.

In addition, the mean of the items about in-group favoritism was 1.52 points, indicating that each question fell between not conforming and not conforming at all (as shown in Table 4), which showed that kindergarten principals considered decisions based on in-group favoritism less frequently. This research result differed from many past research findings, such as Sidanius, Pratto, \& Rabinowitz (1994), who pointed out that im- portant individuals in organizations will give special privileges to in-group members and special care, resulting in bias. However, kindergarten principals rarely apply this kind of in-group favoritism on layoff decisions; perhaps because they believe that only keeping able teachers can achieve the goal of continued organizational survival.

Variance analysis of the data in this study showed that different types of kindergartens exhibited some differences in their layoff decisions. This result further supported the finding by Sisco \& Yu (2010), who stated that institutional characteristics will affect ethical decision-making. The results of variance analysis showed that differences in layoff decisions at different kindergartens were primarily based on the three decision types of in-group favoritism, the ability approach, and the care approach, and that the public good approach did not show significant differences $(\mathrm{F}=1.380, p>.05)$. In terms of decisions based on in-group favoritism layoff, privately operated kindergartens had the highest means, and religious and charitable kindergartens had the lowest means. The post-hoc comparison showed a significant difference $(p<.05)$, indicating that pri- 
Table 4.

Summary of the mean difference $\mathrm{F}$ test of kindergarten types on layoff decisions.

\begin{tabular}{|c|c|c|c|c|c|c|c|c|}
\hline Dimension & Kindergarten type & 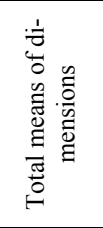 & 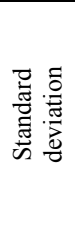 & $\begin{array}{l}\overline{\mathrm{d}} \\
\overline{\mathbf{E}} \\
\bar{z}\end{array}$ & $\underset{\underline{s}}{\vec{s}}$ & 莹 & 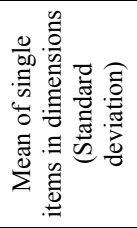 & \begin{tabular}{l}
0 \\
0 \\
0 \\
\multirow{0}{0}{} \\
0 \\
0
\end{tabular} \\
\hline \multirow{4}{*}{$\begin{array}{l}\text { In-group } \\
\text { favoritism decision }\end{array}$} & 1. Privately operated & 8.0809 & 3.048 & 136 & $3.94^{*}$ & .24 & \multirow{4}{*}{$1.52(.633)$} & \multirow{4}{*}{$1>2^{*}$} \\
\hline & 2. Religious and charitable & 6.3571 & 2.422 & 28 & & & & \\
\hline & 3. Large franchise & 6.7619 & 2.234 & 21 & & & & \\
\hline & 4. Affiliated with schools & 6.7273 & 2.760 & 11 & & & & \\
\hline \multirow{4}{*}{$\begin{array}{l}\text { Ability approach } \\
\text { decision }\end{array}$} & 1. Privately operated & 12.2394 & 1.701 & 142 & $3.01^{*}$ & .21 & \multirow{4}{*}{$4.15(.740)$} & \multirow{4}{*}{ n.s. } \\
\hline & 2. Religious and charitable & 12.8929 & 1.707 & 28 & & & & \\
\hline & 3. Large franchise & 12.6818 & 2.338 & 22 & & & & \\
\hline & 4. Affiliated with schools & 13.6364 & 1.629 & 11 & & & & \\
\hline \multirow{4}{*}{$\begin{array}{l}\text { Care approach } \\
\text { decision }\end{array}$} & 1. Privately operated & 13.4676 & 2.529 & 139 & $2.73^{*}$ & .20 & \multirow{4}{*}{$3.38(.944)$} & \multirow{4}{*}{ n.s. } \\
\hline & 2. Religious and charitable & 14.6667 & 2.370 & 27 & & & & \\
\hline & 3. Large franchise & 12.6190 & 3.090 & 21 & & & & \\
\hline & 4. Affiliated with schools & 13.1818 & 2.523 & 11 & & & & \\
\hline \multirow{4}{*}{$\begin{array}{l}\text { Public good } \\
\text { decision }\end{array}$} & 1. Privately operated & 8.3944 & 1.179 & 142 & 1.38 & .14 & \multirow{4}{*}{$4.25(.685)$} & \multirow{4}{*}{-} \\
\hline & 2. Religious and charitable & 8.6429 & 1.723 & 28 & & & & \\
\hline & 3. Large franchise & 8.9545 & 1.214 & 22 & & & & \\
\hline & 4. Affiliated with schools & 8.6364 & 1.567 & 11 & & & & \\
\hline
\end{tabular}

${ }^{*} p<.05$.

vately operated kindergartens were more biased toward the teachers who were close to and trusted by the principals than were religious and charitable kindergartens (religious and charitable kindergartens were less biased). In terms of decisions based on the ability approach, kindergartens affiliated with schools had the highest means, and privately operated kindergartens have the lowest means, and there were significant differences $(p<.05)$. Although the post-hoc comparison did not show a significant difference among different types of kindergartens, this information showed that kindergartens affiliated with schools were more concerned with layoff decisions based on the ability approach than were other types of kindergartens. In other words, when laying off teachers, they would consider the teachers' abilities, qualifications, and performance. In decisions based on the care approach, kindergartens established by religious and charitable groups had the highest mean, and large franchise kindergartens had the lowest mean, and the difference was significant $(p<.05)$. Although the post-hoc comparison did not show significant differences among the different types of kindergartens, this data indicated that religious and charitable kindergartens placed greater emphasis on layoff decisions based on the care approach than other kindergartens, which showed that they were more concerned with caring about the special situations of teachers (as shown in Table 4).

The other point of exploration in this study was how different layoff decisions would affect kindergarten competitiveness and effectiveness. Even though the past study by Guthrie \& Datta (2008) pointed out that there are negative correlations between labor cuts or layoffs and organizational profitability and an increase in organizational assets $(\mathrm{r}=-.29)$, and other studies have pointed out that layoffs may affect employee effectiveness (Manela, 2010), these studies have not been able to further explain which layoff decisions harm competitiveness and effectiveness. Regression analysis of the data in this study showed that having more decisions based on in-group favoritism would be harmful for kindergarten competitiveness (Beta $=$ $-.20, p<.05)$ and kindergarten effectiveness (Beta $=-.20, p$ $<.05$ ), and that having more decisions based on the ability approach would have a greater benefit for kindergarten competitiveness (Beta $=.19, p<.05)$ and kindergarten effectiveness (Beta $=.15, p<.05)$. However, decisions based on the care approach would benefit kindergarten effectiveness (Beta $=.21$, $p<.05$ ) but not kindergarten competitiveness. As for layoff decisions based on the public good approach, the kindergartens did not show major differences and there were no significant effects (as in Table 5). Thus, results of this study more concretely pointed out the value of making decisions using the ability approach in kindergarten competitiveness and effectiveness. At the same time, it explained that decisions based on in-group favoritism would harm kindergarten competitiveness and effectiveness.

\section{Conclusions and Suggestions}

This study was concerned with the necessity for human resources to be restructured or laid off in kindergartens for cost considerations, in the face of falling birth rates and fewer students. This study hoped to explore which layoff decisions could benefit kindergarten effectiveness and competitiveness, as well 
Table 5.

Summary of the regression analysis of layoff decisions, competitiveness, and effectiveness.

\begin{tabular}{ccccc}
\hline \multirow{2}{*}{$\begin{array}{l}\text { Variable } \\
\text { Predictor variable }\end{array}$} & \multicolumn{2}{c}{$\begin{array}{c}\text { Kindergarten } \\
\text { competitiveness }\end{array}$} & \multicolumn{2}{c}{$\begin{array}{l}\text { Kindergarten } \\
\text { effectiveness }\end{array}$} \\
\cline { 2 - 5 } & $\mathbf{B}$ & Beta & B & Beta \\
\hline In-group favoritism decision & $-1.08^{*}$ & -.20 & $-.34^{*}$ & -.20 \\
Care approach decision & .98 & .15 & $.39^{*}$ & .21 \\
Ability approach decision & $1.66^{*}$ & .19 & $.41^{*}$ & .15 \\
Public good decision & -.70 & -.06 & .52 & .14 \\
Constant & 170.01 & - & $37.93^{*}$ & - \\
Sample number & 148 & - & 191 & - \\
F value & $5.19^{*}$ & - & $11.13^{*}$ & - \\
$\mathrm{R}^{2}$ & .13 & - & .19 & - \\
\hline
\end{tabular}

${ }^{*} p<.05$.

as which decisions would negatively effect on effectiveness and competitiveness, when kindergartens were forced to make layoff decisions. At the same time, this study hoped to explore whether there were differences between the layoff decisions in different types of schools. It was found that when Taiwanese kindergarten principals made layoff decisions, they would be inclined toward using the ability approach and public good decisions, and that they would less often use in-group favoritism decisions. They made decisions based on the care approach to a medium degree. However, there were still some differences when comparing different types of kindergartens. In terms of decisions based on in-group favoritism, privately-operated kindergartens had more such considerations than other kindergartens. Decisions based on the care approach received more emphasis at kindergartens established by religious/charitable organizations than at other kindergartens, and decisions based on the ability approach were more often used by kindergartens affiliated with schools than by other kindergartens. In addition, this study investigated which layoff decisions would benefit kindergarten effectiveness and competitiveness. The research results showed that decisions based on in-group favoritism harmed kindergarten competitiveness and operational effectiveness, while decisions using the ability approach positively affected competitiveness and effectiveness. Although care approach decisions could benefit operational effectiveness, they did not significantly enhance competitiveness.

Past studies have warned that layoffs may have negative influences on employee effectiveness. When it is necessary to lay off employees, this study more concretely pointed out the importance of using the ability approach to maintain kindergarten competitiveness and effectiveness. At the same time, it explained that decisions based on in-group favoritism were not good for kindergarten competitiveness and effectiveness. As for the decisions based on the care approach, which are emphasized by Chinese society and organizations, this study found that they could benefit operational effectiveness, but that they did not have a significant effect on elevating competitiveness. This highlighted that if kindergartens wish to emphasize the elevation of competitiveness so that they can continue to exist in an environment of intense competition, kindergarten layoffs should use the ability approach as the highest guiding principle. Ingroup favoritism should not be used at all, as it will have a negative influence on elevating competitiveness; even decisions based on the care approach should not be used, because these do not benefit competitiveness. However, if the goal of a kindergarten is only to enhance effectiveness, then decisions based on the ability approach and the care approach can be used. Finally, this study suggested that privately-operated kindergartens should be concerned with the problem of higher levels of in-group favoritism. Even though both privately-operated kindergartens and religious and charitable kindergartens have low instances of decisions based on in-group favoritism, both types are private kindergartens, and in the intensely competitive early education market, any tiny difference may result in serious problems. Privately-operated kindergartens are prone to a greater number of decisions based on in-group favoritism, and they need to be careful with this issue.

In future research, it is suggested that the teachers' perspective can be used to consider kindergarten layoff decisions; perhaps this will lead to different results. Further, this study found that decisions based on the public good had no significant effect on kindergarten competitiveness and effectiveness. It is possible that all of the kindergartens had high average scores for decisions based on the public good and that they were therefore unable to demonstrate a difference. The other possibility is that there were relatively fewer items about public good decisions, which may have affected the influence on competitiveness and effectiveness. Subsequent research and development can make modifications on this point. This study looks forward to research results from other countries on this issue, as well as international comparative studies, which could be used to understand differences in national cultures in regards to kindergarten layoff decisions.

\section{REFERENCES}

Brabeck, M. (1993). Moral judgment: Theory and research on differences between males and females. In M. J. Larrabee (Ed.), An ethic of care (pp. 33-48). New York: Routledge.

Department of Statistics, Ministry of Education (2012). Numbers of schools, teachers, staff, classes, students and graduates (1950-2011 academic years). http://ebas 1.ebas.gov.tw/pxweb/Dialog/statfile9L.asp

Department of Statistics, Ministry of Education (2008b). Numbers of full-time teachers at schools. http://ebas1.ebas.gov.tw/pxweb/Dialog/statfile9L.asp

Donald, B., Hamilton, L., Susanna, L., \& James, W. (2011). Teacher layoffs: An empirical illustration of seniority versus measures of effectiveness. Education Finance and Policy, 6, 439-454. doi:10.1162/EDFP a 00041

Garg, R. K., \& Jain, S. (2008). Impact of change management on competitiveness: A study of small scale industry in Punjab. Global Journal of Flexible Systems Management, 9, 55-60.

Graen, G. (1976). Role making processes within complex organizations. In M. D. Dunnette (Ed.), Handbook in industrial and organizational psychology (pp. 1201-1245). Chicago: Rand Mcnally.

Graen, G., \& Cashman, J. (1975). A role making model of leadership in formal organizations: A developmental approach. In J. G. Hunt, \& L. L. Larson (Eds.), Leadership frontiers. Kent, Ohio: Kent State University Press.

Groves, K., Vance, C., \& Paik, Y. (2008). Linking linear/nonlinear thinking style balance and managerial ethical decision-making. Journal of Business Ethics, 80, 305-325. doi:10.1007/s10551-007-9422-4

Guthrie, J. P., \& Datta, D. K. (2008). Dumb and dumber: The impact of downsizing on firm performance as moderated by industry conditions. Organization Science, 19, 108-123. 


\section{Y.-G. CHEN, J.-N. CHENG}

doi:10.1287/orsc. 1070.0298

Hegtvedt, K. A., \& Killian, C. (1999). Fairness and emotions: Reactions to process and outcomes of negotiations. Social Forces, 78, 269-303.

Husted, B. W., \& Allen, D. B. (2008). Toward model of cross-cultural business ethics: The impact of individualism and collectivism on the ethical decision-making process. Journal of Business Ethics, 82, 293-305. doi:10.1007/s10551-008-9888-8

Joseph, F. H., Rolph, E. A., \& Ronald, L. T. (1987). Multivariate data and analysis with reading. New York: MacMillan Publishing Co.

Lin, H. M. (1999). Establishment of close subordinate relationships. Journal of Education and Psychology, 22, 323-354.

Manela, P. K. (2010). Responses of school social workers to job transitions: Transfers, layoffs, job loss, and retirement. Children \& Schools 32, 187-189. doi:10.1093/cs/32.3.187

New Teacher Project (2010). A smarter teacher layoff system: How quality-based layoffs can help schools keep great teachers in tough economic times.

http://search.proquest.com/docview/870282759?accountid=12699

Nyaw, M. K., \& Ng, I. (1994). A comparative analysis of ethical beliefs: A four country study. Journal of Business Ethics, 13, 543-555. doi:10.1007/BF00881299

Ordonez, L., Connolly, T., \& Coughlan, R. (2000). Multiple reference points in satisfaction and fairness assessment. Journal of Behavioral Decision Making, 13, 329-344.

doi:10.1002/1099-0771(200007/09)13:3<329::AID-BDM356>3.0.C $\underline{\mathrm{O} ; 2-\mathrm{Q}}$

Patten, P., Ricks, O., \& ERIC Clearinghouse on Elementary and Early Childhood Education, C. L. (2000). Child care quality: An overview for parents. ERIC Digest.

http://web.ebscohost.com/ehost/detail?vid=4\&sid=be77b8e3-c00f-4c
96-8baf-524d5e4c9f25\%40sessionmgr10\&hid=117\&bdata=Jmxhbm c9emgtdHcmc210ZT1laG9zdC1saXZl\#db=eric\&AN=ED447969

Payne, D., \& Joyner, B. E. (2006). Successful US entrepreneurs: Identifying ethical decision-making and social responsibility behaviors. Journal of Business Ethics, 65, 203-217. doi:10.1007/s10551-005-4674-3

Porter, M. E. (1980). Competitive strategy. New York: The Free Press.

Rest, J. R. (1986). Moral development: Advances in research and theory. Westpert, CT: Praeger.

Schweitzer, M. E., \& Gibson, D. E. (2008). Fairness, feelings, and ethical decision-making: Consequences of violating community standards of fairness. Journal of Business Ethics, 77, 287-301.

doi:10.1007/s10551-007-9350-3

Sidanius, J., Pratto, F., \& Rabinowitz, I. L. (1994). Ingroup identification, social dominance, orientation, and differential intergroup social allocation. Journal of Social Psychology, 134, 151-167. doi: $10.1080 / 00224545.1994 .9711378$

Sisco, L. A., \& Yu, N. (2010). The rhetoric of Chinese layoff memos. Business Communication Quarterly, 73, 326-330. doi:10.1177/1080569910377276

$\mathrm{Su}$, Q. H. (2007). Correlations between elementary school principal decision-making styles and ethical decision making. Master's Thesis, Tainan: Graduate Institute of Educational Entrepreneurship and Management, National Tainan University.

Varma, A., \& DeNisi, A. S. (1996). Interpersonal affect and performance appraisal: A field study. Personnel Psychology, 49, 341-360. doi:10.1111/j.1744-6570.1996.tb01803.x

West, R. P. (2004). Indicators of school quality: School characteristics that predict success in raising academic achievement. Salt Lake City: Utah Special Education Consortium. 